一論文—

（日本化学会誌，1995，（1）, p. 57～62）

(C) 1995 The Chemical Society of Japan

\title{
アゾ系色素を側鎖に有するポリメタクリル酸メチルの 誘電性及び非線形誘電性
}

\author{
(1994年10月 3 日受理)
}

矢野興 紀*. 中村桂子**

\begin{abstract}
側鎖の一部に二次の超分子分極率の大きい4-アミノ-4'-ニトロアゾベンゼン(DO3）が結合したポリ メタクリル酸メチル(PMMA) の複素誘電率及び二次非線形誘電率を測定した. $-180 \sim 150{ }^{\circ} \mathrm{C}$ 範囲 の誘電正接 $(\tan \delta)$ の測定から 4 種類の緩和過程のあることを見いだした. そのうち 3 種類は PMMA ホモポリマーにも存在する緩和である．これらの緩和は，低温側から，吸着水の関係した緩和，DO3 が付いていない側鎖の緩和，DO3 を低濃度に含んでいる相中の主鎖のミクロブラウン運動による緩和 (主分散)，高い濃度でDO3 を含んでいる相における主分散と帰属された.

二次誘電率 $\varepsilon_{2}$ の経時変化を DO3-PMMA をポーリング処理した試料について種々の温度で測定し

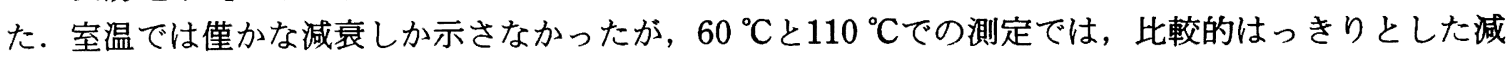
衰を示した。これらの温度での実測值は KWW(Kohlrausch-Williams-Watts) 式よりも biexponential 式によく適合することがわかった。この結果もDO3 基が環境の違う二つの相中に存在することによる ものと推定することができる.
\end{abstract}

\section{1 緒言}

レーザーの非可視光を短波長化して可視光化を可能にする非線 形光学材料の研究が活発である. とりわけ無機物に比べて, 格段 に大きな非線形感受率をもつものが多数あることなどの理由か ら，近年，有機物が特に注目を集めている112).

二次の非線形性の発現には, 分子が一定の方向に配向していな ければならず, 結晶学的には, 反転対称要素をもたないパッキン グ状態をとる必要がある. 効率よく二次の非線形性を発現させる には，超分子分極率 $\boldsymbol{\beta}$ の大きな分子を配向させればよい，その ため， $\beta$ の大きな分子を高分子中にドーブした後，ポーリング （高電界処理）を行ってドーパントを配向させる手段がしばしば とられる. 光の電場によって大きく分極し，しかもその誘起双極 子の非対称性が大きければよい， $\beta$ の大きな分子としてよく知ら れているものに， $p$-ニトロアニリン，4-ジメチルアミノ $-44^{\prime}-ニ$ トロスチルベン(DANS) など122)がある.これらを高分子中にド 一プする方法では, 透明で任意の厚さのフィルムを二次の非線形 性の大きな材料にすることが出来る反面, 次のようないくつかの 問題がある．それは，十分なドープ量を確保出来ない場合が多い こと，ドーブした分子に十分な配向を与えるのにエ夫がいるこ と, せっかく配向した分子が高分子の分子運動によって楥和する

京都工芸㵶維大学㵶維学部高分子学科, 606 京都市左京 区松ヶ渏御所海道町

** 現在 三菱電線工業株式会社中央研究所電線材料研究部, 660 尼崎市東向島西之町 8 番地
こと文〜6)などである.これらの問題を解決するために, $\boldsymbol{\beta}$ の大き な分子をモノマーの段階で混ぜておいて，重合を行ったり，高分 子に結合させて双極子の配向の䌅和を抑える試及7) 10)などが行 われている.いずれにしても，この種の材料は，配向された双極 子の緩和現象の十分な把握が必要である. そこで本研究では, $\beta$ の大きい4-アミノ-4'-ニトロアソベンゼン(以下 DO3 と略記す る）をポリメタクリル酸メチル(以下 PMMA と略記する) の側 鎖の一部に導入したポリマーを合成し，その誘㫣的性質を PMMA ホモポリマーと比較検討したうえ, 二次誘電率の経時変 化を種々の温度で測定し，その减衰挙動について検討した。

\section{2 実験}

\section{1 試料}

メタクリル酸メチル(以下 MMA と略記する) は常法にしたが って精製し、メタクリル酸クロリド(以下 $\mathrm{MACl}$ と略記する）は 真空蒸留によって精製したものを用いた。モノマー $(\mathrm{MMA}+\mathrm{MACl}) 10 \mathrm{~g}$ に対して0.4 mmol の重合開始郕 2,2'-アソ ビスイソブチロニトリルと15 g のよく精製脱水されたベンゼン とをアンプルに入れて封じた．MMA と MAClの重量比が 8: $2,6: 4,5: 5$ になるように 3 種類のアンフルを用意した. 重合は $65{ }^{\circ} \mathrm{C}$ で 5 時間行った。得られたポリマー $(\mathrm{MMA} / \mathrm{MACl}$ 共重合 体）はシクロヘキサン中に滴下することによって沈股回収され， 再びベンゼンに溶解後, シクロヘキサン中に再沈殿させることに よって精製した。こうして得られた $\mathrm{MMA} / \mathrm{MACl}$ 共重合体を無

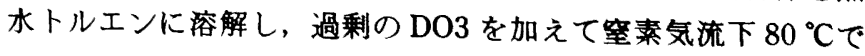




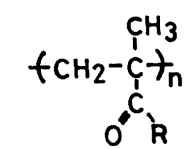

$-\mathrm{R}: \quad-\mathrm{O}-\mathrm{CH}_{3}$

or

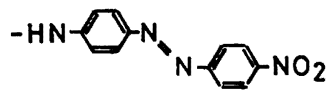

Fig. 1 The chemical formula for DO3-PMMA

3 時間かきまぜながら反応を行った ${ }^{11)}$. 未反応酸クロリドはメタ ノールによってエステル化した，沈殿物をメタノールでソックス レー抽出することによって, 未反応 DO3 を除去した.

$80^{\circ} \mathrm{C} て ゙ 24$ 時間真空乾燥後, 種々の測定に用いた. このように して得られたDO3を側鎖に修飾されたポリマーを以下 DO3PMMA と略記する. DO3-PMMA の分子構造式を図 1 に示す.

比較のために用いた PMMA は，市販のもの(和光純薬) を卜 ルエン/メタノール系で再沈精製したものを真空乾燥し, ホット プレスを用いて $160{ }^{\circ} \mathrm{C} て ゙$ 製膜して使用した.

\subsection{NMR 測定}

General Electrics 社製の QE-300 NMR 測定装置を用いた。溶 媒には重水素化シメチルスルホキシドを用い, 室温で測定した.

\subsection{DSC 測定}

試料のガラス転移温度を示差走査熱量計 DSC3100(マックサイ エンス社製）により評価した。測定は窒素䨌囲気下，昇温速度 $10^{\circ} \mathrm{C} / \mathrm{min}$ の条件で行った.

\section{4 赤外吸収スペクトル}

富士電機社製 FT-IR FIRIS 100を用いて透過法で行った。 キ ヤスト溶媒にはジメチルスルホキシドを用いた.

\section{5 紫外吸収スペクトル}

島津製作所のUV-160を使用した. シメチルスルホキシドに溶 解してスペクトルを測定した.

\section{6 複素誘電率測定}

発振器(KENWOOD AG-203) からの信号を，精密抵抗とコ ンデンサーから成るコンペンセーターに，また反転増幅した信号 を試料に入力する. 両方の信号が丁度キャンセルされるように， オシロスコープ(日立 V-1050) を見ながらコンペンセーターを 調整し，そのときの抵抗值とコンデンサーとの值から試料の複素 誘電率を求めた．測定の確度は $\tan \delta$ が 10-2 で 2 3\%である.

真空ホットプレスにより DO3-PMMA を $195{ }^{\circ} \mathrm{C}$, 圧縮成形し て得られた膜を， 24 時間， $80{ }^{\circ} \mathrm{C}$ 真空乾燥した後，両面に金を 真空蒸着しセル内にセットした後, 室温で真空乾燥後, セル内に 窒素カスを満した. 測定は三端子法で行った. PMMA はホット プレスで $160{ }^{\circ} \mathrm{C} て ゙$ 製膜し，後は同じように行った.

測定周波数は $30,100,300,1000 \mathrm{~Hz}$ ，測定温度範囲はー180～ $150{ }^{\circ} \mathrm{C}$ である. 試料を冷却後, 昇温しながら測定を行った. 昇温 速度は30〜 $50{ }^{\circ} \mathrm{C} / \mathrm{h}$ である. 温度測定には銅ーコンスタンタン熱 龟対を使用した。

\section{7 非線形誘電率の測定}

発振器(KENWOOD AG-203) 加らの正弦波信号 $(\omega / 2$ $\pi=100 \mathrm{~Hz}$ ）を約30倍に増幅して試料に印加する．応答信号のう ち $\omega$ 成分は補償回路によって十分に小さくし，2 個の $2 \omega$ のバ ンドパスフィルターとノッチ周波数 $3 \omega$ のノッチフィルターと で，二次の応答信号を検出した ${ }^{12)}$ 。信号の大きさは，オシロス コープ（日立 V-1050）上で読み取った。試料の作製方法は，誘 電測定に用いたものと基本的に同じである.ポーリング処理はセ ル内で行った.

\section{3 結果と考察}

DO3-PMMA のうち重合時の MMA と MAClの比 MMA: $\mathrm{MACl}=8: 2$ の試料の DSC 測定の結果を図 2 に示す. $135{ }^{\circ} \mathrm{C}$ ガラス転移に対応する変化が見られるほか, $96{ }^{\circ} \mathrm{C}$ 付近にも僅加 な変化が観測された．このように二つのガラス転移温度があるの は, 試料が相分離しているためと思われる. $\mathrm{MMA}: \mathrm{MACl}=6$ :

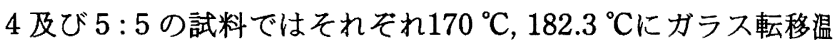
度が観測されたが，低温側のガラス転移温度に対する変化は，は っきりとは観測されなかった，これら二つの試料については，溶 解する溶媒が見つからなかったため, 以下の测定には MMA： $\mathrm{MACl}=8: 2$ の試料たけを用いた.

DO3-PMMA の重水素化シメチルスルホキシド溶液の高分解 能 ${ }^{1} \mathrm{H}$ NMR スペクトルより，DO3 色素の置換度は約 $6.3 \mathrm{~mol} \%$ と評価された。図 3 にFT-IR 測定の結果を示す. DO3 と PMMA との単なる混合物(以下 DO3/PMMA と略記する) での スペクトルの一部もあわせて示してあるが, DO3-PMMA には $\mathrm{CONH}$ の面内振動である $1022 \mathrm{~cm}^{-1}$ に吸収がみられ，DO3 色素 の側鎖への修飾が確認できる.

分子量を測定するために，色素を修飾する前の $\mathrm{MMA} / \mathrm{MACl}$ 共重合体の一部をメタノールでエステル化することによって PMMA とした．このPMMA のベンゼン溶液の固有粘度 $[\eta]$ を 求め, 次式13)加分子量を算出し, $4.3 \times 10^{5}$ を得た.

$$
[\eta]=6.27 \times 10^{-3} M^{0.76} \quad\left(30^{\circ} \mathrm{C}\right)
$$

ここで， $M$ は分子量で, 溶液の濃度の単位は $\mathrm{g} / 100 \mathrm{~m} l$ である.

DO3-PMMA と DO3/PMMA(DO3; 6 wt\%) それぞれのジ チルスルホキシド溶液の紫外吸収スペクトルを図 4 示す．側鎖 に色素を修飾することにより，アゾベンゼンの吸収スペクトルに

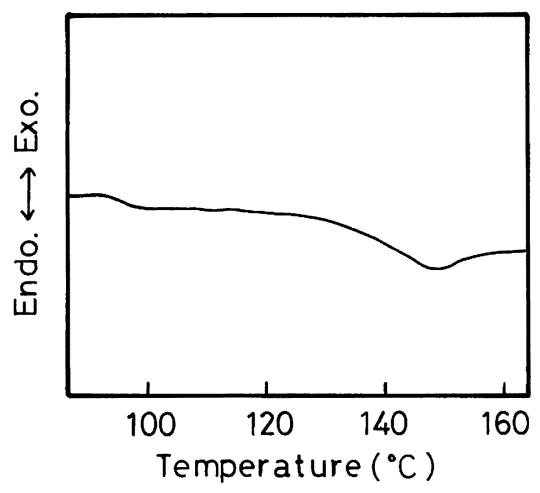

Fig. 2 DSC scan on a sample of DO3-PMMA measured at the heating rate of $10^{\circ} \mathrm{C} / \mathrm{min}$ 


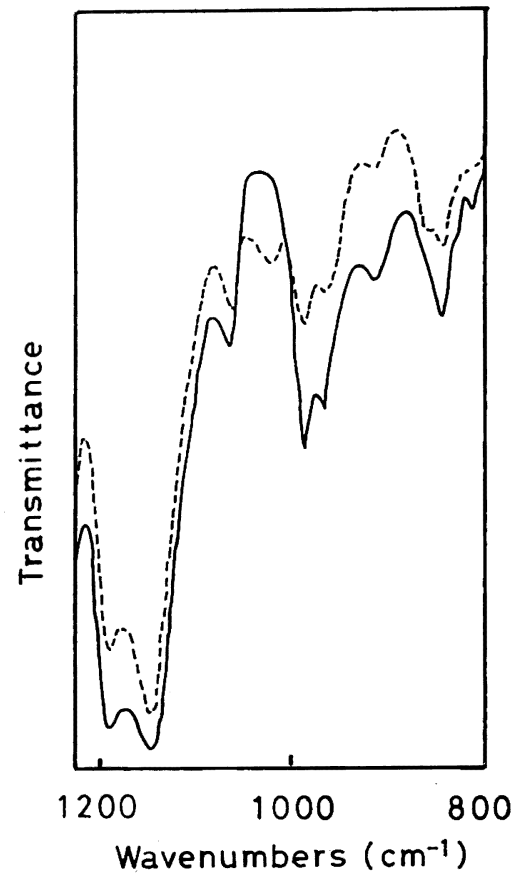

Fig. 3 IR spectra for samples: (…) DO3-PMMA and (-) DO3/PMMA

明瞭な深色効果が認められた.

\section{1 誘電緩和}

図 5 に PMMA の誘電率と誘電正接 $(\tan \delta)$ の温度依存性を示 す. $37^{\circ} \mathrm{C}$ 付近にみられる大きな損失ピークは側鎖緩和 $(\beta$ 緩和 $)$ で，より高温側の損失ピーク(より高周波の測定では，側鎖緩和 のピークと重なるため明瞭でない）は，主分散によるものである

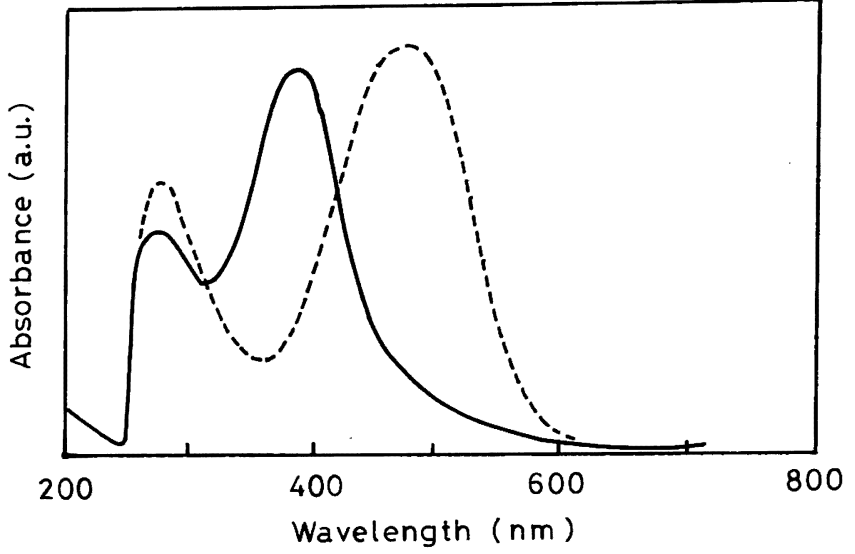

Fig. 4 UV-visible absorption of DO3/PMMA (solid line) and DO3-PMMA (dashed line) in DMSO

と考えられている14).これらの他にー $73^{\circ} \mathrm{C}$ 付近にも小さな損失 ピークのあることがわかる.

図 6 は DO3-PMMA の周波数30,100,300, $1000 \mathrm{~Hz}$ での誘電 率と $\tan \delta$ の温度変化である. PMMA とよく似た損失曲線であ るが，PMMAにみられた主分散はかなり小さくなって側鎖緩和 の肩となって現れている。この損失が現れたことは，前述の DSCの結果とよく対応する．また，さらに高温での損失曲線の 立ち上がり温度は, DSC 測定における高温側のガラス転移温度 と対応しているので，これが主たる主分散であると思われる。 D03 のついた側鎖を比較的多く含んだ相と, DO3をあまり含ま ない相（緩和強度からみてきわめて少ない）とから成るものと考 えられる.

DO3-PMMA の側鎖緩和は, PMMAのそれと比へて緩和強度

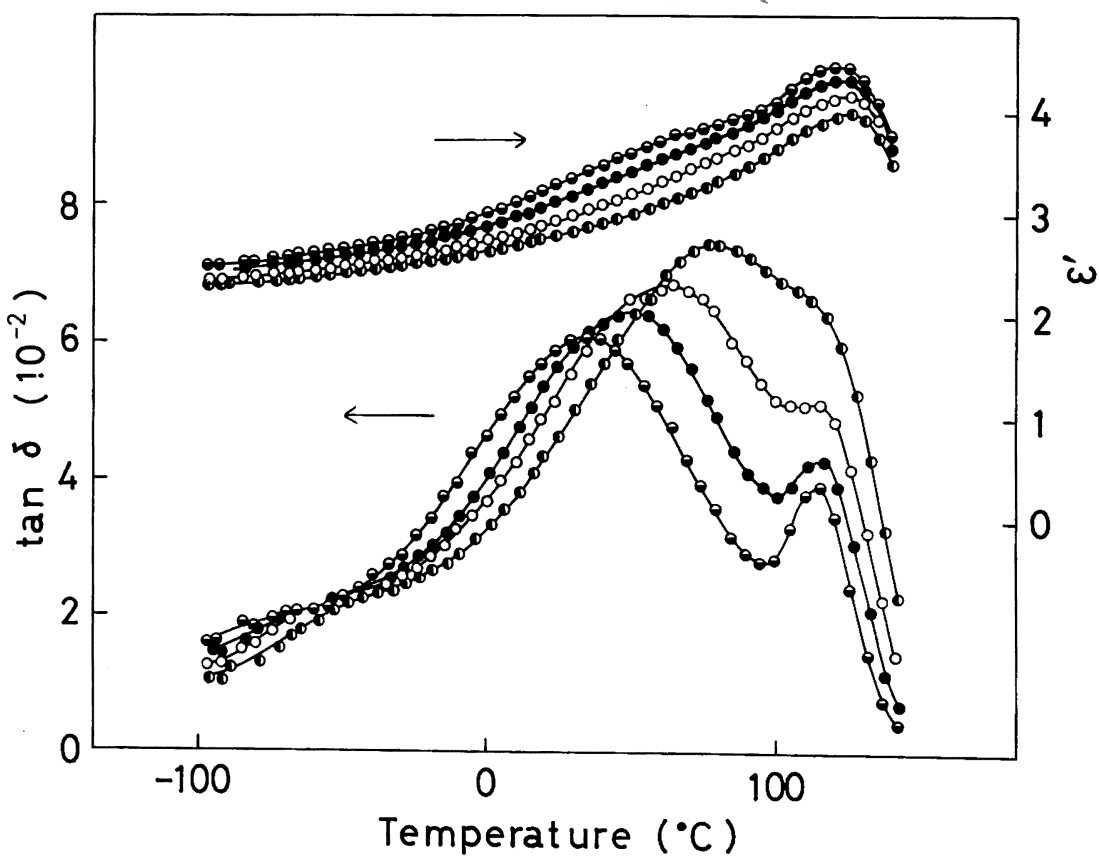

Fig. 5 Temperature dependence of dielectric constant and dielectric loss tangent for PMMA at various frequencies (O) 30 ; 100 ; (O) 300; (D) $1000 \mathrm{~Hz}$ 


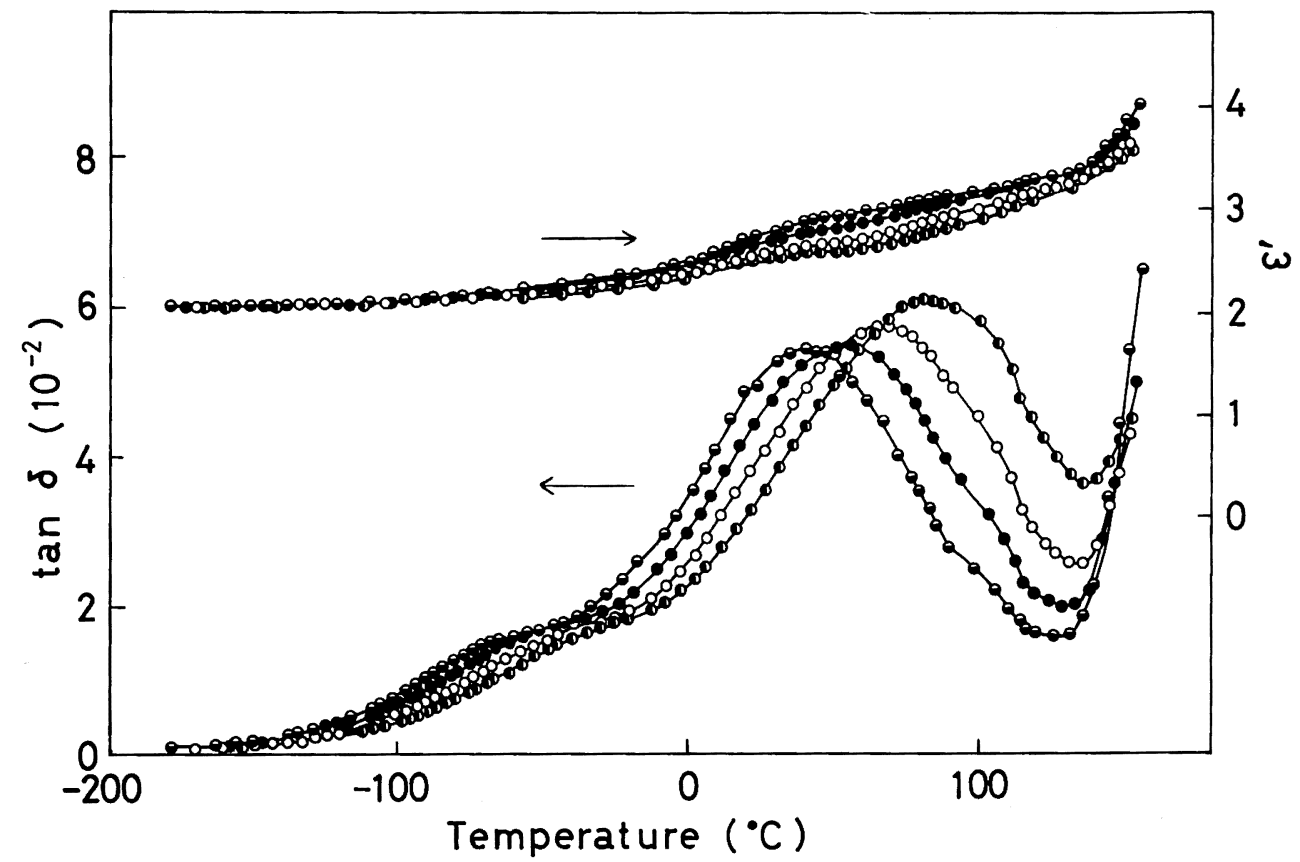

Fig. 6 Temperature dependence of dielectric constant and dielectric loss tangent for DO3-PMMA at various frequencies (O) 30 ; (O) 100 ; (O) 300 ; (D) $1000 \mathrm{~Hz}$

は小さくなったものの, 損失ピークになる温度はほとんど変化が 見られなかった．これはPMMA とp-ニトロアニリンとの単な る混合物では，アミノ基と高分子の側鎖との間で水素結合を形成

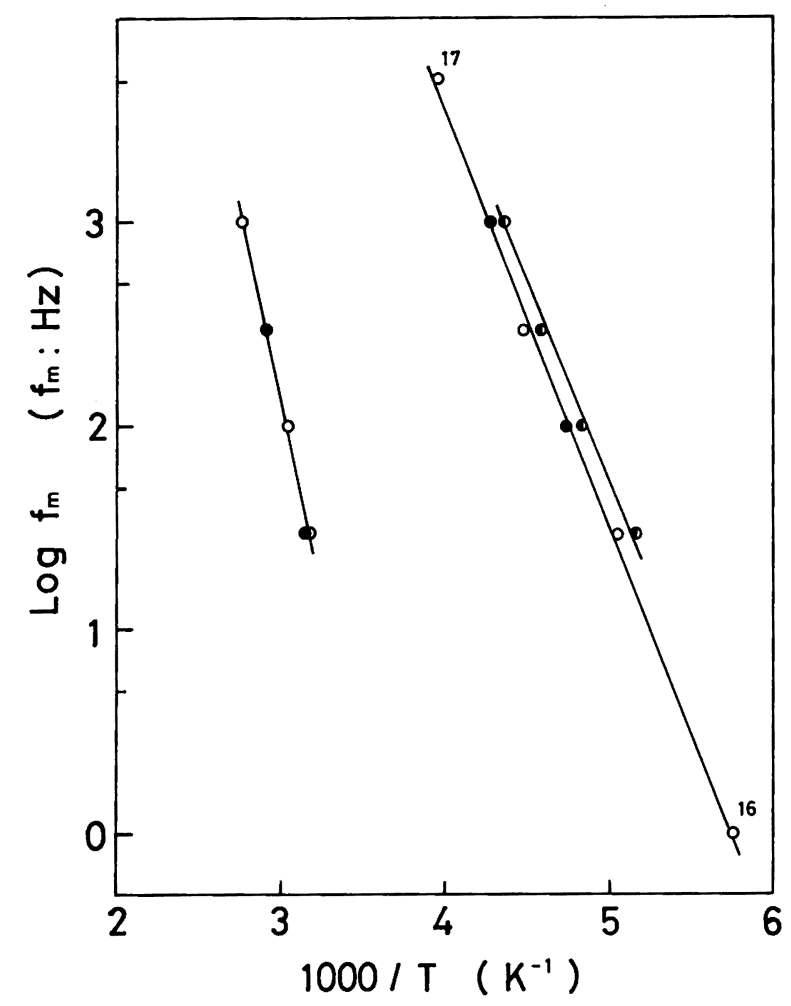

Fig. 7 The loss maximum frequency vs. reciprocal absolute temperature for samples

(O) PMMA; (O) DO3-PMMA (same in Fig. 6)

(D) DO3-PMMA (hydrated at $66 \%$ relative humidity) Numbers refer to references
するため，側鎖緩和が強い影響を受ける15)のとは対照的である. Arrhenius プロット(因 7) の直線の勾配から評価した活性化工 ネルギーは, PMMA, DO3-PMMA 共に $95 \mathrm{~kJ} / \mathrm{mol}$ で，損失誘 電率 $\varepsilon^{\prime \prime}$ の極大值で比較すると, DO3-PMMA は PMMA のそれ よりも約 $25 \%$ 小さい. 前述のように, DO3 の置換度は約 6.3 mol\%なので，楥和に寄与する側鎖メトキシカルボニル基の数かi 少なくなった以上に減少している. D03 近傍にある側鎖メトキ シカルボニル基の運動がかなり抑制されていることが推察され る.

PMMA で見られた $-73{ }^{\circ} \mathrm{C}$ 付近の緩和も明瞭に現れている. DO3-PMMA を相対湿度 $66 \%$ で調湿した試料について，誘電測 定を行った．その結果を図 8 に示す． $0{ }^{\circ} \mathrm{C}$ 以上の高温側では吸湿 による影響はほとんどなかったが， $-73^{\circ} \mathrm{C}$ 付近の損失は大きく なった．この緩和は絶乾状態では現れない16)ことから，調湿し ていない方の試料にも殿量の吸着水が残っていたものと思われ

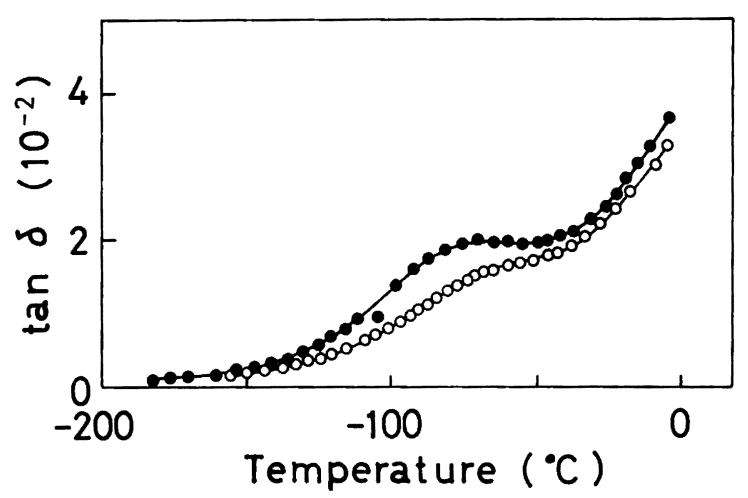

Fig. 8 Temperature dependence of dielectric loss tangent for samples

(O) DO3-PMMA (same in Fig. 6); (O) DO3PMMA (hydrated at $66 \%$ relative humidity) 
る.図7のArrhenius プロットに見られるように, Scheiber

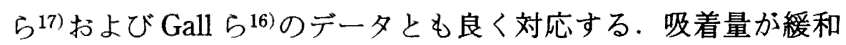
周波数に若干影響することもわかった.

\section{2 二次誘電率}

\section{二次の電気変位 $D_{2}$ は電場振幅 $E_{0}$ と}

$$
D_{2}=(1 / 2) \varepsilon_{2} E_{0}{ }^{2}+(1 / 2) \varepsilon_{4} E_{0}{ }^{4}+(15 / 32) \varepsilon_{6} E_{0}{ }^{6}+
$$

の関係がある18)ので, 高次の項が無視できる範囲で $D_{2}$ の $E_{0}{ }^{2}$ 依 存性から求めることができる. $D_{2}$ は二次電気変位, $\varepsilon_{2}, \varepsilon_{4}, \varepsilon_{6}$ は それぞれ二次, 四次, 六次誘電率である.

試料は, $140{ }^{\circ} \mathrm{C}, 31 \mathrm{MV} / \mathrm{m}$ で 30 分間ポーリングを行い, 電圧 を印加したまま所定の温度に下がるのを待ってから測定を開始し た. 所定の温度に保持したときの二次誘電率 $\left|\varepsilon_{2}\right|$ が時間とともに 减衰していく様子すなわち, ポーリングによって形成された非対 称性が崩れていく様子を調ぺた. ポーリングを終了してから $t$ 時 間後の $\left|\varepsilon_{2}\right|$ の値を $\left|\varepsilon_{2}(t)\right|$ とし, $\left|\varepsilon_{2}(t)\right| /\left|\varepsilon_{2}(0)\right|$ を所定温度での 保持時間でプロットしたのが, 図 9 である.

はじめに，これら減衰曲線とKohlrausch-Williams-Watts (KWW) の式19)20)

$$
\left|\varepsilon_{2}(t)\right| /\left|\varepsilon_{2}(0)\right|=\exp \left\{-(t / \tau)^{\beta}\right\}
$$

との適合を調べた。ここで， $\tau$ は緩和時間， $\beta$ は $0<\beta \leqq 1$ なる Parameter で緩和時間の広がりを表す．測定值と関数系との適合 には, 京都大学大型計算機センターのプログラムライブラリー非 線形最小二乗法プログラム(SALS) を利用した。図 9 の $110{ }^{\circ} \mathrm{C}$ の結果の場合について例示したように，測定值と計算值では特に 短い時間において，系統的な不一致がみられた．そこで，2種類 の緩和機構から成っているものと考えて,

$$
\left|\varepsilon_{2}(t)\right| /\left|\varepsilon_{2}(0)\right|=\theta_{1} \exp \left(-t / \tau_{1}\right)+\theta_{2} \exp \left(-t / \tau_{2}\right)
$$

を用いて再度測定値との適合を調べた．ここで， $\tau_{1}, \tau_{2}$ はそれそ れ，速い緩和と遅い緩和の時定数であり， $\theta_{1}, \theta_{2}$ はそれそれの緩 和の分率である。この適合操作にもSALSを利用した。適合曲 線を図 9 中の実線で示した，測定值と計算値とはかなりよく一

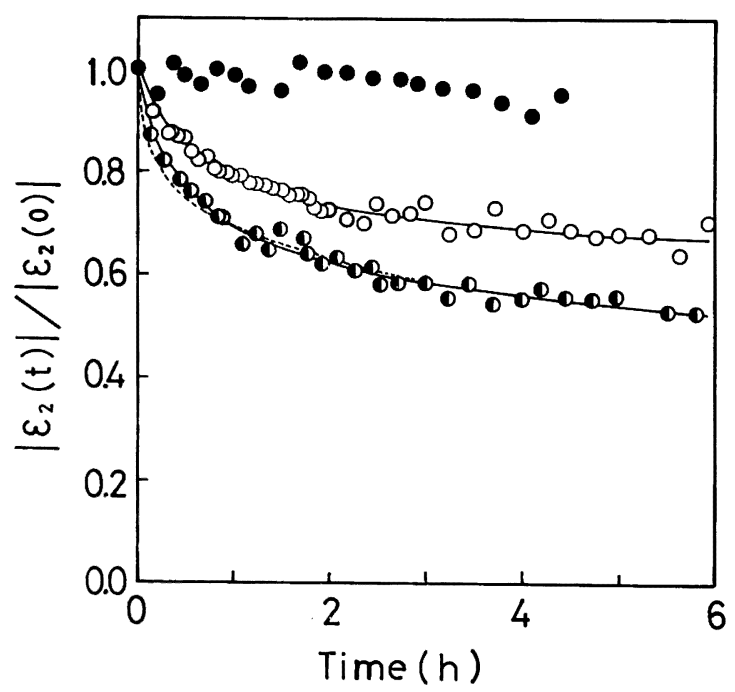

Fig. 9 Normalized second order dielectric constant vs. time at various temperature

(O) 23 ; (O) 60 ; (D) $110{ }^{\circ} \mathrm{C}$

The solid line and the dashed line are fits to the biexponential function and KWW equation, respectively
Table 1 Fitting parameter by biexponential equation for poled DO3-PMMA at 60 and $110^{\circ} \mathrm{C}$

\begin{tabular}{c|ccc}
$T\left({ }^{\circ} \mathrm{C}\right)$ & $\tau_{1}(\mathrm{~h})$ & $\tau_{2}(\mathrm{~h})$ & $\theta_{1}: \theta_{2}$ \\
\hline 60 & 0.64 & 50.4 & $23: 77$ \\
110 & 0.50 & 22.0 & $30: 70$
\end{tabular}

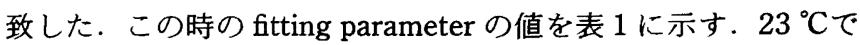

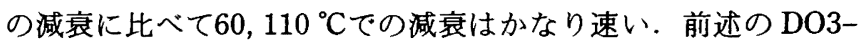

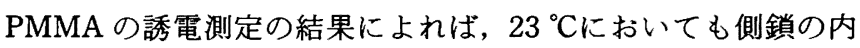
部回転は起こっているので, この側鎖の運動は, DO3 色素分子 の配向緩和にあむり影響を与えていないように思われる. $60{ }^{\circ} \mathrm{C}$ と $110{ }^{\circ} \mathrm{C}$ での減衰は，主に主鎖の局所運動によるものと考えら れ，これはガラス転移温度からの温度差に依存する. 速い緩和は， DO3 色素をあまり含をない相中の DO3 色素の配向緩和に相当 し, 遅い緩和は, DO3 色素を多く含む相中の DO3 色素の配向緩 和と考えられる.

\section{以上の結果から以下のことが結論される.}

1. DO3 $6.3 \mathrm{~mol} \%$ 側鎖に結合したDO3-PMMA は，DO3 を低濃度に含んでいる相と比較的高濃度に含んでいる相とにわか れている.

2. DO3 近傍の側鎖(メトキシカルボニル基）の内部回転はか なり抑制されている結果，DO3-PMMA の側鎖緩和の緩和強度 は小さくなっている．従って，この側鎖楥和は DO3 の配向緩和 に余り影響を与えない。

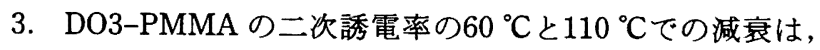
KWW (Kohlrausch-Williams-Watts) 式よりもbiexponential 式 によく適合している.DO3 基が環境の違う二つの相中に存在す ることを示唆している

1）高分子学会編, “高分子新素材便覧” 丸善(1989) pp. $107 \sim 115$.

2) G. T. Boyd, Polymers for Nonlinear Optics, in "Polymers for Electronic and Photonic Applications" ed. by C. P. Wong, Academic Press(1993) pp. 467 505.

3) H. L. Hampsch, J. Yang, G. K. Wong, J. M. Torkelson, Macromolecules, 23, 340(1990).

4) S. HU. G. O. Carlisle, D. R. Martinez, J. Mater. Sci. Lett., 11, 794 (1992).

5) T. Goodson III, C. H. Wang, Macromolecules, 26, 1837 (1993).

6) M. Stahelin, C. A. Walsh, D. M. Burland, R. D. Miller, R. J. Twieg, W. Volksen, J. Appl. Phys., 73, 8471 (1993).

7) I. Teraoka, D. Jungbauer, B. Reck, D. Y. Yoon, R. Twieg, C. G. Willson, J. Appl. Phys., 69, 2568(1991).

8) C. A. Walsh, D. M. Burland, V. Y. Lee, R. D. Miller, B. A. Smith, R. J. Twieg, W. Volksen, Macromolecules, 26, 3720 (1993).

9) A. Zerroukhi, A. Trouillet, D. Blanc, B. Boinon, A. Cachard, J. P. Montheard, J. Appl. Polym. Sci., 51, 1165(1994).

10) C. Baehr, B. Glusen, J. H. Wendorff, E. G. J. Staring, Macromol. Rapid Commun., 15, 327 (1994)

11) G. Linoli, E. Mannucci, C. Bergonzi, J. Polym. Sci., A-1, 8, 1481(1970).

12) K. Tohyama, O. Yano, T. Soen, Rep. Prog. Polym. Phys. Jpn., 31, 415(1988).

13) T. G. Fox, J. B. Kinsinger, H. F. Mason, E. M. Schuele, Polymer, 3, 71(1962). 
14) N. G. McCrum, B. E. Read, G. Williams, "Anelastic and Dielectric Effects In Polymeric Solids", John Wiley \& Sons (1967) pp. 238 255.

15) M. S. Dionisio, J. J. Moura-Ramos, G. Williams, Polymer, 35, 1705(1994).

16) W. G. Gall, N. G. McCrum, J. Polym. Sci., 50, 489(1961).
17) D. J. Scheiber, D. J. Mead, J. Chem. Phys., 27, 326(1957)

18) T. Furukawa, K. Nakajima, N. Koizumi, M. Date, Jpn. J. Appl. Phys., 26, 1039(1987).

19) T. Kohlrausch, Pogg. Ann. Phys., 91, 198(1854).

20) G. Williams, D. C. Watts, Trans. Faraday Soc., 66, $80(1970)$.

\title{
Linear and Nonlinear Dielectricity of Poly (methyl methacrylate) Containing Azo Compound in the Side Chain
}

\author{
Okimichi YANO* and Keiko NAKAMURA \\ Department of Polymer Science and Engineering, Kyoto Institute of Technology; \\ Matsugasaki Sakyo-ku Kyoto-shi 606 Japan
}

Dielectric properties of nonlinear optical chromophore functionalized poly (methyl methacrylate) (PMMA) with 4-amino-4'-nitroazobenzene(DO3) have been investigated in the temperature range from -180 to $150{ }^{\circ} \mathrm{C}$. Four relaxation processes were found. Three of these relaxation processes were also observed in PMMA homopolymer. The four processes are respectively attributed to the relaxation due to absorbed moisture, the relaxation of the side chain without DO3 group, the primary relaxation of microphase with a low concentration of $\mathrm{DO} 3$ group, and the primary relaxation of microphase with a high concentration of $\mathrm{DO} 3$ group, in order of ascending temperature.

Time dependence of the second-order dielectric constant $\left|\varepsilon_{2}\right|$ for a sample obtained by poling DO3PMMA have been measured at various temperatures. At room temperature, the decay was slight. At $60{ }^{\circ} \mathrm{C}$ and $110^{\circ} \mathrm{C}$, the values of $\left|\varepsilon_{2}\right|$ after $6 \mathrm{~h}$ from the end of poling decayed by $30 \sim 50 \%$ of the initial values of $\left|\varepsilon_{2}\right|$. Observed values at $60^{\circ} \mathrm{C}$ and $110^{\circ} \mathrm{C}$ was able to be described by the biexponential equation better than by KWW (Kohlrausch-Williams-Watts) equation indicating that DO3 groups exist in at least two different kinds of environment. 